\begin{tabular}{|c|c|}
\hline 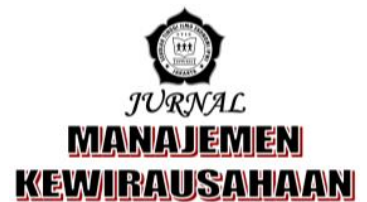 & $\begin{array}{r}\text { p-ISSN 1858-1048 } \\
\text { e-ISSN 2654-9247 } \\
\text { http://ejurnal.stieipwija.ac.id/index.php/jmk } \\
\text { DOI: http://dx.doi.org/10.33370/jmk.v17i1.391 } \\
\text { Jurnal Manajemen Kewirausahaan Vol. 17 No. 01 - Juni } 2020 \\
\text { Submit: 27 Apr 2020; Review: 07 Mei 2020; Publish: 30 Jun } 2020\end{array}$ \\
\hline
\end{tabular}

\title{
PENGARUH LINGKUNGAN KERJA DAN STRES KERJA TERHADAP KINERJA KARYAWAN PADA PT NUSAMULTI CENTRALESTARI TANGERANG
}

\section{(THE INFLUENCE OF WORK ENVIRONMENT AND WORK STRESS ON EMPLOYEES PERFORMANCE IN PT. NUSAMULTI CENTRALESTARI TANGERANG)}

\author{
Oleh: \\ Joni Heruwanto'), Retno Wahyuningsih"), Rasipan ${ }^{3)}$, Ergo Nurpatria4) \\ joniheruwanto@yahoo.com ${ }^{1)}$, retnown23@gmail.com ${ }^{2}$, ipan081267@yahoo.com ${ }^{3)}$, \\ ergo.mustgo@gmail.com ${ }^{4}$ \\ Sekolah Tinggi Ilmu Ekonomi IPWI Jakarta1,2,3,4)
}

\begin{abstract}
Work environment and stress are factors that affect the performance of employees of PT. Nusamulti Centralestari. This study aims to determine the effect of the work environment and stress on the performance of employees of PT. Nusamulti Centralestari. Research by taking the entire population of 54 employees with a saturated sample technique (census). The questionnaire instrument is a closed five Likert scale. The study was conducted in quantitative descriptive through inference analysis. Analysis through validity, reliability and multiple linear regression tests while hypothesis testing is done by $t$-test and F-test. Research produces findings Work environment has a positive effect on employee performance; Job stress has a positive effect on employee performance. To improve employee performance, it is recommended to improve work environment and work stress on employee performance.
\end{abstract}

Keywords: Work Environment, Work Stress, Employee Performance.

\begin{abstract}
ABSTRAK
Lingkungan kerja dan stres merupakan faktor yang mempengaruhi kinerja karyawan PT. Nusamulti Centralestari. Penelitian ini bertujuan untuk mengetahui pengaruh lingkungan kerja dan stres terhadap kinerja karyawan PT. Nusamulti Centralestari. Penelitian dengan mengambil seluruh populasi yaitu 54 karyawan dengan teknik sampel jenuh (sensus). Instrumen kuesioner secara tertutup lima skala Likert. Penelitian dilakukan secara kuantitatif deskriptif melalui analisis inferensi. Analisis melalui uji validitas, reabilitas dan regresi linier ganda sedangkan pengujian hipotesis dilakukan dengan uji-t dan uji-F. Penelitian menghasilkan temuan Lingkungan kerja berpengaruh positif terhadap kinerja karyawan; Stres kerja berpengaruh positif terhadap kinerja karyawan. Untuk meningkatkan kinerja karyawan disarankan dilakukan perbaikan lingkungan kerja dan stres kerja pada kinerja karyawan.
\end{abstract}

Kata Kunci: Lingkungan Kerja, Stres Kerja, Kinerja Karyawan

Jurnal Manajemen Kewirausahaan Vol. 17 No. 01 - Juni 2020

LP2M Sekolah Tinggi Ilmu Ekonomi IPWI Jakarta 


\section{PENDAHULUAN}

Setiap organisasi dituntut untuk dapat mengoptimalkan sumber daya manusia dan bagaimana sumber daya manusia dikelola. Pengelolaan sumber daya manusia tidak lepas dari faktor karyawan yang diharapkan berprestasi sebaik mungkin demi mencapai tujuan organisasi. Karyawan merupakan asset utama organisasi dan mempunyai peran strategis di dalam organisasi yaitu sebagai pemikir, perencana dan pengendali aktivitas organisasi.

Suatu perusahaan tentu mengharapkan pegawai bekerja secara produktif dengan pengaturan sumber daya manusia secara profesional, salah satu faktor yang dapat meningkatkan produktifitas karyawan adalah kinerja karyawan karena merupakan hal yang bersifat individual. Masalah yang mempengaruhi kinerja karyawan sangatlah banyak dan ini sebagai tantangan tersendiri untuk perusahaan dalam mengelola sumber daya manusia karena keberhasilan suatu perusahaan itu tergantung pada sumber daya manusia yang berkualitas.

Kinerja karyawan adalah salah satu faktor yang mempengaruhi tingkat keberhasilan organisasi. Kinerja merupakan hasil kerja yang dapat dicapai oleh seorang atau sekelompok orang dalam organisasi bersangkutan secara legal, tidak melanggar hukum dan sesuai dengan moral atau etika (Moeheriono, 2012). Usaha untuk meningkatkan kinerja karyawan, di antaranya adalah dengan memperhatikan stres kerja. Stres merupakan suatu kondisi seseorang mengalami ketegangan karena adanya kondisi yang mempengaruhinya, kondisi tersebut dapat diperoleh dari dalam diri seseorang maupun lingkungan diluar diri seseorang. Stres dapat menimbulkan dampak yang negatif terhadap keadaan psikologis dan biologis bagi karyawan. Menurut (Hasibuan, 2013) stres kerja adalah suatu kondisi ketegangan yang mempengaruhi emosi, proses berpikir, dan kondisi seseorang.

Sedarmayanti dalam (Dhermawan, 2012) mengungkapkan bahwa faktor lingkungan kerja bisa berupa kondisi fisik kantor yang meliputi penerangan, suhu udara, dll yang mampu meningkatkan suasana kondusif dan semangat kerja serta berpengaruh terhadap kinerja pegawai. Lingkungan kerja terdiri dari dua dimensi yaitu lingkungan fisik yang bersifat nyata dan dimensi lingkungan non fisik yang bersifat tidak nyata, lingkungan fisik berkenan dengan kondisi tempat atau ruangan dan kelengkapan material atau peralatan yang diperlukan karyawan untuk bekerja, sedangkan non fisik berkenan dengan suasana sosial atau pergaulan (komunikasi) antar personil di lingkungan unit kerja masing-masing atau dalam keseluruhan organisasi kerja. Lingkungan kerja fisik merupakan peralatan, bangunan kantor, perabot, tata bangunan termasuk juga kondisi jasmaniah tempat pegawai bekerja yang meliputi; desain, tata letak, pencahayaan, warna, suhu, kelembapan, dan sirkulasi udara. Sedangkan yang termasuk ke dalam lingkungan non fisik yaitu; suasana sosial, pergaulan antar personil, peraturan kerja (tata tertib) dan kebijakan perusahaan, sehingga dapat disimpulkan bahwa suasana lingkungan kerja adalah kondisi atau keadaan lingkungan kerja baik dalam arti fisik maupun psikis yang mempengaruhi suasana hati orang bekerja yang mencakup beberapa indikator yaitu; fasilitas kerja, tata ruang, kenyamanan, hubungan dengan teman kerja, dan kebebasan berkreasi.

PT. Nusamulti Centralestari sangat membutuhkan kinerja karyawan yang tinggi untuk meningkatkan produktivitas perusahaan, karena dengan memiliki tanggung jawab yang tinggi, tujuan yang realitas, rencana kerja yang menyeluruh, berani mengambil resiko yang dihadapi, maka produktivitas perusahaan akan meningkat, oleh karena itu salah satunya adalah meminimalisir stres kerja dan menciptakan lingkungan kerja yang baik serta kondusif.

Sebagai manusia biasa, karyawan pada PT. Nusamulti Centralestari tentu dihadapkan dengan kondisi dilematis. Di 
satu sisi mereka harus bekerja untuk fokus pada visi perusahaan, disisi lain mereka memiliki kebutuhan dan keinginan yang perlu mendapat perhatian dari perusahaan. Kondisi ini tentunya akan menimbulkan karyawan yang mengalami stres kerja yang berakibat pada kinerja dalam melaksanakan tugas pekerjaan.

\section{TUJUAN PENELITIAN}

Sesuai dengan permasalahan di atas, maka tujuan umum penelitian ini adalah untuk mengetahui pengaruh lingkungan kerja dan stres terhadap kinerja karyawan PT. Nusamulti Centralestari. Tujuan tersebut selanjutnya dapat diuraikan sebagai berikut:

1. Untuk mengetahui pengaruh lingkungan kerja terhadap kinerja karyawan pada PT. Nusamulti Centralestari.

2. Untuk mengetahui pengaruh stres kerja terhadap kinerja karyawan pada PT. Nusamulti Centralestari.

\section{TELAAH LITERATUR DAN PENGEMBANGAN Lingkungan Kerja}

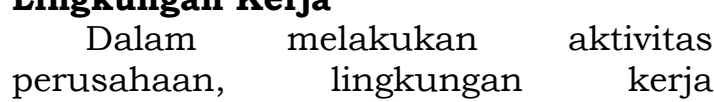
merupakan segala kondisi yang berada di sekitar para pekerja, sehingga baik secara langsung maupun secara tidak langsung dapatmempengaruhi dirinya dalam melaksanakan tugas yang dibebankan. Lingkungan kerja yang baik dan menyenangkan akan dapat menimbulkan semangat dan kegairahan kerja, dan sebaliknya jika lingkungan kerja yang tidak menyenangkan dapat mengurangi semangat dan kegairahan kerja. Lingkungan kerja di dalam suatu perusahaan atau instansi sangat penting diperhatikan oleh pimpinan karena lingkungan kerja yang baik mempunyai pengaruh terhadap efektivitas yang bekerja dalam perusahaan. Di dalam usaha untuk membuat perencanaan lingkungan kerja maka perlu mengkaji dan menentukan aspek-aspek pembentukan lingkungan kerja itu sendiri. Menurut Siagian (2014:57) menyatakan bahwasecara garis besar, lingkungan kerja terdapat dua jenis yaitu: 1) Lingkungan Kerja Fisik. Lingkungan kerja fisik adalah semua keadaan berbentuk fisik yang terdapat di sekitar tempat kerja dan dapat mempengaruhi karyawan. Ada beberapa kondisi fisik dari tempat kerja yang baik yaitu: a) Bangunan tempat kerja di samping menarik untuk dipandang juga dibangun dengan pertimbangan keselamatan kerja. b) Tersedianya peralatan kerja yang memadai. c) Tersedianya tempat istirahat untuk melepas lelah, seperti kafetaria baik dalam lingkungan perusahaan atau yang mudah di capai karyawan. d) Tersediannya tempat ibadah keagamaan seperti masjid dan mushollah untuk karyawan. e) Tersedianya sarana angkutan, baik yang di peruntukan karyawan maupun angkutan umum yang nyaman, murah dan mudah diperoleh. 2) Lingkungan Kerja Non Fisik. Lingkungan kerja non fisik adalah lingkungan kerja yang menyenangkan dalam arti terciptanya hubungan kerja yang harmonis antar karyawan dan atasan, karena pada hakekatnya tidak hanya mencari uang saja, akan tetapi bekerja merupakan bentuk aktivitas yang bertujuan untuk mendapatkan kepuasan.

Dari beberapa pendapat di atas dapat disimpulkan bahwa lingkungan kerja fisik merupakan keadaan berbentuk fisik yang mencakup setiap hal fasilitas organisasi yang dapat mempengaruhi karyawan dalam melaksanakan pekerjaan atau efektivitas. Sedangkan lingkungan kerja non fisik. Lingkungan kerja non fisik tidak dapat tangkap oleh pancaindra manusia namun dapat dirasakan oleh perasaan misalnya, hubungan antara karyawan dengan pimpinan.

\section{Stres Kerja}

Stres kerja merupakan satu situasi yang mungkin dialami manusia pada umumnya dan karyawan pada khususnya di dalam sebuah organisasi atau perusahaan. Stres kerja menjadi masalah yang penting karena situasi itu 
dapat mempengaruhi kepuasan kerja dan kinerja. Sehingga perlu penanganan dalam upaya mencapai tujuan dan sasaran perusahaan. Dalam banyak kasus, hal itu bisa mempengaruhi kinerja karyawan sehingga harus menjadi perhatian pihak perusahaan terutama manajemen personalia.

Stres kerja merupakan suatu kondisi ketegangan yang menimbulkan adanya ketidakseimbangan fisik serta psikis pekerja, yang mempengaruhi emosi, proses berpikir, dan kondisi seorang karyawan. Dalam kaitannya dengan pekerja, semua dampak dari stress tersebut akan menuju kepada menurunnya performansi, efisiensi dan produktivitas kerja yang bersangkutan.

Dampak dari stres kerja dapat di kelompokkan menjadi 3 kategori menurut Robbins (2012) sebagai berikut: a) Gejala Fisiologis, bahwa stres kerja dapat menciptakan perubahan dalam metabolisme, meningkatkan laju detak jantung, dan pernapasan, menimbulkansakit kepala dan menyebabkan serangan jantung. b) Gejala Psikologis, stres yang berkaitan dengan pekerjaan dapat menyebabkan ketidakpuasan dalam bekerja. Dalam bekerja muncul ketegangan, kecemasan, mudah marah, kebosanan, konsentrasi berkurang dan menunda-nunda pekerjaan. c) Gejala Perilaku, mencangkup perubahan dalam kebiasaan hidup, gelisah, merokok, nafsu makan berlebihan, dan gangguan tidur.

\section{Kinerja}

Kinerja merupakan suatu fungsi dari motivasi dan kemampuan untuk menyelesaikan tugas atau pekerjaan seseorang yang sepatutnya memiliki derajat kesediaan dan tingkat kemampuan tertentu, di mana kesediaan dan kemampuan seseorang tidaklah cukup efektif untuk mengerjakan sesuatu tanpa pemahaman yang jelas tentang apa yang akan dikerjakan dan bagaimana mengerjakannya. Kinerja merupakan perilaku nyata yang ditampilkan setiap orang sebagai prestasi kerja yang dihasilkan oleh karyawan sesuai dengan perannya dalam perusahaan di mana hal yang sangat penting dalam upaya perusahaan untuk mencapai tujuannya.

Kinerja adalah hasil kerja secara kualitas dan kuantitas yang dicapai oleh seorang pegawai dalam melaksanakan tugasnya sesuai dengan tanggung jawab yang diberikan kepadanya. Mangkunegara (2014:75). Menurut Sutrisno (2016) faktor yang mempengaruhi kinerja karyawan adalah a) Efektivitas dan Efisiensi. Dalam hubungannya dengan kinerja organisasi, maka ukuran baik buruknya kinerja diukur oleh efektivitas dan efisien. Misalnya adalah bagaimana proses terjadinya efisiensi dan efektivitas organisasi. Dikatakan efektif bila mencapai tujuan, dikatakan efisien bila hal itumemuaskan sebagai pendorong mencapai tujuan. b) Otoritas dan Tanggung Jawab. Dalam organisasi yang baik, wewenang dan tanggung jawab telah didelegasikan dengan baik, tanpa adanya tumpang tindih tugas. Masingmasing karyawan yang ada dalam organisasi mengetahui apa yang menjadi haknya dan tanggung jawabnya dalam rangka mencapai tujuan organisasi. Kejelasan wewenang dan tanggung jawabsetiap orang dalam suatu organisasi akan mendukung kinerja karyawan tersebut. c) Disiplin. Secara umum, disiplin menunjukkan suatu kondisi atau sikap hormat yang ada pada diri karyawan terhadap peraturan dan ketetapan perusahaan. Masalah disiplin karyawan yang ada di dalam organisasi baik atasan maupun bawahan akan memberikan corak terhadap kinerja organisasi. Kinerja organisasi akan tercapai apabila kinerja individu maupun kelompok ditingkatkan. d) Inisiatif. Inisiatif seseorang berkaitan dengan daya pikir, kreativitas dalam bentuk ide untuk merencanakan sesuatu yang berkaitan dengan tujuan organisasi merupakan daya dorong kemajuan yang akhirnya akan mempengaruhi kinerja.

\section{Kerangka Penelitian}

Kerangka pengaruh lingkungan kerja dan stres kerja terhadap kinerja 
karyawan dapat digambarkan sebagai berikut:

Gambar 1

Kerangka Penelitian

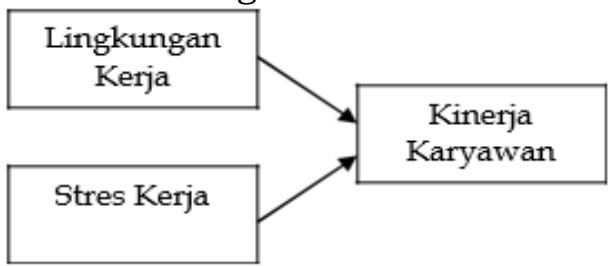

Berdasarkan uraian kerangka pemikiran di atas, maka peneliti mengajukan beberapa hipotesis dalam penelitian ini sebagai berikut:

H1: Lingkungan Kerja berpengaruh terhadap Kinerja Karyawan pada PT. Nusamulti Centralestari.

H2: Stres Kerja berpengaruh terhadap Kinerja Karyawan pada PT Nusamulti Centralestari.

\section{METODE PENELITIAN Sampel Penelitian}

Sampel Jenuh (Sampel Sensus) Menurut Arikunto (2012:104) jika jumlah populasinya kurang dari 100 orang, maka jumlah sampelnya diambil secara keseluruhan, tetapi jika populasinya lebih besar dari 100 orang maka bisa diambil $10-15 \%$ atau $20-25 \%$ dari jumlah populasinya.

Berdasarkan penelitian ini karena jumlah populasinya tidak lebih besar dari 100 orang responden, maka penulis mengambil $100 \%$ jumlah populasi yang ada pada PT. Nusamulti Centralestari yaitu sebanyak 54 orang responden. Dengan demikian penggunaan seluruh populasi tanpa harus menarik sampel penelitian sebagai unit observasi disebut sebagai teknik sensus.

\section{Desain Penelitian}

Variabel yang digunakan dalam penelitian adalah 1) Variabel Bebas (Independen) yaitu Lingkungan Kerja (X1) dan Stres Kerja (X2). 2) Variabel terikat (Dependen) yaitu Stres Kerja (Y)

\section{Operasionalisasi Variabel}

Operasionalisasi variabel penelitian dapat dikemukakan sebagai berikut:
Tabel 1

Operasionalisasi Variabel

\begin{tabular}{|c|c|c|}
\hline Variabel/ Konsep & Indikator & Skala \\
\hline $\begin{array}{l}\text { Lingkungan kerja (X1) } \\
\text { Sumbor: } \\
\text { (Dhermawan, dkk. 2012) }\end{array}$ & $\begin{array}{ll}\text { a. Kebersihan } \\
\text { b. Keamanan } \\
\text { e. Fasilitas } \\
\text { d. Sirkulasi } \\
\text { Udara } \\
\text { e. Kebisingan } \\
\text { Suara } \\
\text { f. Hubungan } \\
\text { Karyawan } \\
\text { 5. Perilaku } \\
\text { h. Suasana } \\
\text { Kerja }\end{array}$ & $1-5$ \\
\hline Variabel/ Konsep & Indikcator & Skala \\
\hline $\begin{array}{l}\text { Strea kerja }(\times 2) \\
\text { Sumbar: } \\
\text { Charlas D. } \\
\text { Sabielousa(dalam Hefaifak } \\
\text { Gaffar,2012:g) }\end{array}$ & 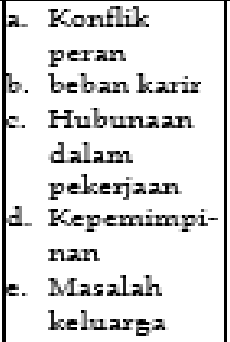 & $1-5$ \\
\hline $\begin{array}{l}\text { Kinerja karyawan }(Y) \\
\text { Swmbar: } \\
\text { Anwar } \\
\text { PrabuMangkwogara } \\
(2014: 75)\end{array}$ & \begin{tabular}{|l|} 
a. Kerapihan \\
b. Kebehasilan \\
c. Kemampuan \\
d. Kepuasan \\
e. Kecepatan \\
f. Sarana dan \\
Prasarana \\
5. hasil kerja \\
h. kekompalc- \\
kan \\
Hubungan \\
dengan \\
rekan kerja \\
Kemandirian
\end{tabular} & $1-5$ \\
\hline
\end{tabular}

\section{Metode Analisis Uji Validitas}

Uji validitas adalah suatu derajat ketepatan antara data yang sesungguhnya terjadi dengan data yang dikumpulkan oleh peneliti. Validitas sebagai salah satu derajat ketepatan atau kendala pengukuran instrumen mengenai isi pertanyaan (Sugiyono, 2012:124). Untuk mengukur instrumen yang dipakai maka peneliti menggunakan korelasi Bivariate Pearson (Produk Momen Person). Dari hasil analisis akan didapat nilai korelasi ( $r$ hitung). Jika $r$ hitung lebih besar dari $r$ tabel, maka instrumen (pertanyaan) 
tersebut valid dan bisa diteruskan ke penelitian. Jika $r$ hitung lebih kecil dari $r$ tabel, berarti pertanyaan tersebut tidak valid. Pertanyaan tersebut harus diganti atau dihilangkan.

\section{Uji Reliabilitas}

Reliabilitas adalah indeks yang menunjukkan sejauh mana suatu alat pengukur dapat dipercaya atau dapat diandalkan. Uji reliabilitas dilakukan terhadap keseluruhan butir pertanyaan yang telah valid. Uji reliabilitas dilakukan dengan metode Cronbach's Alpha. Reliabilitas terpenuhi jika nilai Cronbach's Alpha > 0,6.

\section{Uji Normalitas}

Normalitas harus terpenuhi yang menunjukkan bahwa data variabel penelitian berasal dari data variabel yang berdistribusi normal. Normalitas data pada analisis regresi linear ganda dalam penelitian ini dilakukan secara grafik yaitu menggunakan Normal PPlot. Normalitas terpenuhi jika titik-titik pada grafik normal P-P Plot menyebar di sekitar dan mengikuti diagonal grafik.

\section{Uji Multikolinearitas}

Multikolinearitas yaitu adanya korelasi yang sangat kuat antar variabel bebas tidak diharapkan sehingga pengujian dilakukan untuk memastikan tidak terjadi multikolinearitas yang menunjukkan variabel bebas satu dengan lainnya (independen). Tidak terjadinya multikolinearitas atau terpenuhi uji pengujian dilakukan dengan melihat nilai VIF dan Tolerance.

\section{Uji Asumsi Autokorelasi}

Model regresi yang baik adalah yang tidak terjadi autokorelasi di mana pengujian dilakukan dengan melihat nilai Durbin-Watson hasil pengolahan data dibandingkan dengan nilai dl dan du pada Durbin-Watson.

\section{Uji Asumsi Heteroskedasitas}

Heteroskedasitas tidak diharapkan sehingga pengujiannya dilakukan untuk membuktikan bahwa model persamaan regresi ganda tidak memiliki masalah heteroskedasitas. Pengujian dilakukan secara grafis yaitu dengan melihat titiktitik pada grafik scatter plot. Apabila titik-titik tersebar acak tidak membentuk suatu pola tertentu seperti segitiga, segiempat, lengkung yang beraturan dan sebagainya maka uji asumsi ini terpenuhi.

Setelah uji asumsi terpenuhi maka dilakukan analisis regresi linear ganda. Hasil analisis regresi linear ganda yang utama adalah nilai koefesien determinasi R Square (R2).

\section{HASIL PENELITIAN DAN PEMBAHASAN Uji Validitas dan Reliabilitas}

Terdapat 4 butir pertanyaan yang gugur pada variabel $\mathrm{X} 1$ dan $\mathrm{X} 2$ yaitu (X1.3, X1.6 X2.1, X2.9) sedangkan variabel pada variabel $Y$ untuk semua butir pertanyaan lebih besar dari 0,268. Nilai Cronbach's Aalpha untuk setiap variabel lebih besar dari 0,6. Hal ini menunjukkan bahwa masing-masing indikator pada variabel lingkungan kerja, stres kerja dan kinerja karyawan keseluruhan telah valid dan reliabel sehingga dapat digunakan dalam penelitian.

\section{Uji Asumsi Klasik \\ Uji Normalitas}

Model regresi berdistribusi normal karena grafik normal P-Plot mengikuti garis diagonal.

\section{Uji Multikolineritas}

Lingkungan Kerja dan Stres Kerja memiliki nilai tolerance mendekati angka 1.00 dan nilai VIF berada di seputar angka 1 dan tidak lebih dari 10. Sehingga dapat disimpulkan bahwa tidak ada masalah multikolineritas.

\section{Uji Autokorelasi}

Nilai Durbin-Watson hasil perhitungan DW $=1.902$. Berdasarkan kategori yang telah ada, nilai DW termasuk dalam range $1.65<\mathrm{DW}$ $(1.902)<2.35$ yang berarti tidak terjadi autokorelasi. Oleh karena itu analisis regresi linear ganda dapat dilanjutkan. 


\section{Uji Heteroskedastisitas}

Grafik scatter plot memperlihatkan bahwa titik-titik hasil perhitungan menyebar secara acak diatas dan dibawah titik origin serta tidak membentuk pola tertentu. Hal ini dapat dikatakan bahwa analisis regresi ganda benar-benar linierkarena tidak memiliki masalah heteroskedstisitas pada model regresi.

\section{Analisis Regresi}

Berdasarkan analisis data menggunakan program SPSS diperoleh hasil regresi Pengaruh Lingkungan Kerja dan Stres Kerja terhadap Kinerja Karyawan pada PT. Nusamulti Centralestari.

Tabel 2

Analisis Regresi

\begin{tabular}{|c|c|c|c|c|c|}
\hline \multirow{2}{*}{ Model } & \multicolumn{2}{|c|}{$\begin{array}{l}\text { Unstandardize } \\
\text { d Coefficients }\end{array}$} & \multirow{2}{*}{$\begin{array}{c}\begin{array}{c}\text { Standar } \\
\text { dized } \\
\text { Coeffici } \\
\text { ents }\end{array} \\
\text { Beta }\end{array}$} & \multirow[t]{2}{*}{$\mathrm{T}$} & \multirow[t]{2}{*}{ Sig. } \\
\hline & B & $\begin{array}{l}\text { Std. } \\
\text { Error }\end{array}$ & & & \\
\hline \multirow{3}{*}{$\begin{array}{l}\text { 1.(Cons- } \\
\text { tant) } \\
\text { Lingukn } \\
\text { gan } \\
\text { Kerja } \\
\text { Stress } \\
\text { Kerja }\end{array}$} & $\begin{array}{c}27,13 \\
7\end{array}$ & 3,454 & & 7,856 & 000 \\
\hline & 240, & ,076 & ,382 & 3,149 & ,003 \\
\hline & 224 & 091 & 297 & 2,453 & .018 \\
\hline
\end{tabular}

a. Dependent Variable: Kinerja Karyawan

Sumber: Data Penelitian yang diolah, 2019

Dari tabel di atas dapat disusun model persamaan regresi linier ganda berdasar kolom B. Model persamaan regresi linier ganda hasil penelitian adalah sebagai berikut:

$\mathrm{Y}=27.137+0.240 \mathrm{X} 1+0.224 \mathrm{X} 2$

$$
\text { (0.003) (0.018) }
$$

Model persamaan regresi linier ganda hasil analisis tersebut dapat diartikan sebagai berikut 1) Nilai konstanta sebesar a $=27.137$, artinya bahwa jika X1 dan X2 dianggap konstan maka Y akan bernilai positif. Nilai koefesien regresi $\mathrm{X} 1$ sebesar $\mathrm{b} 1=0.240$ menunjukkan bahwa X1 berpengaruh terhadap Y dengan arah positif. 3) Nilai koefesien regresi X2 sebesar b2 $=0.224$ menunjukkan bahwa X2 berpengaruh terhadap Y dengan arah positif.

Koefesien Determinasi (R2)

Tabel 3

Model Summary ${ }^{\mathrm{b}}$

\begin{tabular}{|l|l|l|l|l|}
\hline $\begin{array}{l}\text { Mo } \\
\text { del }\end{array}$ & R & $\begin{array}{l}\text { R } \\
\text { Squar } \\
\text { e }\end{array}$ & $\begin{array}{l}\text { Adjusted } \\
\text { Square }\end{array}$ & $\begin{array}{l}\text { Std. } \\
\text { Error of } \\
\text { the } \\
\text { Estimate }\end{array}$ \\
\hline 1 &, $519^{\mathrm{a}}$ &, 269 &, 240 & 2,49579 \\
\hline
\end{tabular}

a. Predictors: (Constant), Stres Kerja, Lingkungan Kerja

Sumber: Data Penelitian yang diolah, 2019

Dari tabel di atas diperoleh nilai koefesien determinasi ganda (Adjust $\mathrm{R}$ Square) sebesar 0.269. nilai $\mathrm{R} 2=0.269$ hal ini menunjukkan pengertian bahwa kinerja karyawan (Y) dipengaruhi sebesar $26.9 \%$ oleh variabel lingkungan kerja (X1) stres kerja (X2) sedangkan sisanya $(100 \%-26.9 \%=73.1 \%)$ disebabkan oleh variabel lain yang tidak diteliti. Hasil analisis berikutnya berupa tabel anova yang digunakan untuk menguji hipotesis keempat yaitu pengaruh lingkungan kerja dan stres kerja terhadap kinerja karyawan.

\section{Uji Hipotesis Uji F}

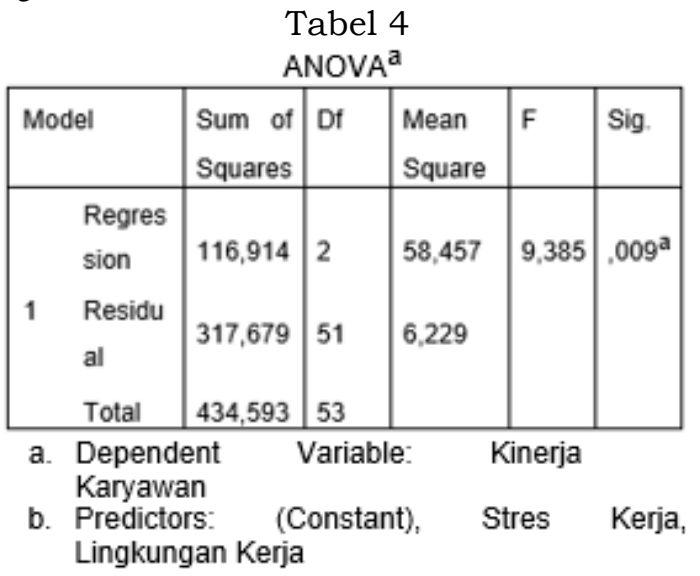

Sumber: Data Penelitian yang diolah, 2019

Pengaruh Lingkungan Kerja (X1) terhadap Kinerja Karaywan (Y) Variabel lingkungan kerja memiliki nilai t hitung $>\mathrm{t}$ tabel $(3.149>1.675)$ atau Sig. $\mathrm{t}<\mathrm{a}=$ 
$0.003<0.05$, makaH10 ditolak dan $\mathrm{H1a}$ diterima, artinya terdapat pengaruh yang signifikan Lingkungan Kerja (X1) terhadap Kinerja Karyawan (Y) pada PT. Nusamulti Centralestari.

Berdasarkan hasil analisis padatabel di atas yakni uji anova diperoleh $\mathrm{f}$ hitung sebesar 9,385 dengan tingkat signifikan sebesar 0.009, maka dapat dikatakan bahwa Lingkungan Kerja (X1) dan Stres Kerja (X2) secara bersama-sama berpengaruh positif terhadap Kinerja Karyawan (Y) pada PT. Nusamulti Centralestari.

\section{Uji $t$}

Tabel 5

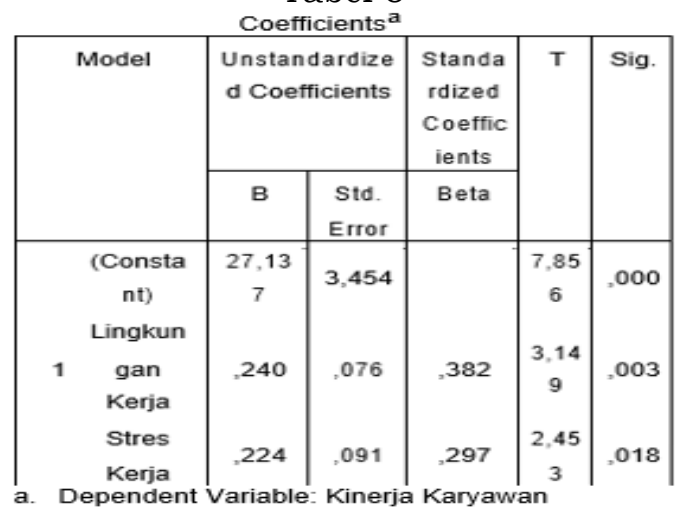

Sumber: Data Penelitian yang diolah, 2019

Pengaruh Lingkungan Kerja (X1) terhadap Kinerja Karyawan (Y). Variabel lingkungan kerja memiliki nilai t hitung $>\mathrm{t}$ tabel $(3.149>1.675)$ atau Sig. $\mathrm{t}<\mathrm{a}=$ $0.003<0.05$, maka H1o ditolak dan H1a diterima, artinya terdapat pengaruh yang signifikan Lingkungan Kerja (X1) terhadap Kinerja Karyawan (Y) pada PT. Nusamulti Centralestari.

Variabel stres kerja memiliki nilai t hitung $>\mathrm{t}$ tabel $(2.453>1.675)$ atau Sig. $\mathrm{t}<\mathrm{a}=0.018<0.05$, maka H10 ditolak dan H1a diterima, artinya terdapat pengaruh yang signifikan Stres Kerja (X1) terhadap Kinerja Karyawan (Y) pada PT. Nusamulti Centralestari.

\section{Pembahasan}

Berdasarkan hasil penelitian bahwa model persamaan regresi linier ganda yaitu, $\mathrm{Y}=27.137+0.240 \mathrm{X} 1+0.224 \mathrm{X} 2$.

\section{Pengaruh Lingkungan Kerja terhadap Kinerja Karyawan}

Dari hasil analisis yang dilakukan bahwa Lingkungan kerja memiliki pengaruh yang signifikan terhadap Kinerja Karyawan.

Pengaruh lingkungan kerja terhadap kinerja karyawan ditunjukkan oleh nilai koefesien regresi lingkungan kerja sebesar $\mathrm{b} 1=0.240$ pada model persamaan regresi linier ganda $\mathrm{Y}=$ $27.137+0.240 \mathrm{X} 1+0.224 \mathrm{X} 2$. Maka nilai thitung Lingkungan Kerja (X1) sebesar 3.149 sedangkan nilai ttabel dengan $\mathrm{df}=$ 51 adalah sebesar 1.675. Maka Ho ditolak dan $\mathrm{Ha}$ diterima, dapat dinyatakan bahwa Lingkungan Kerja (X1) memiliki pengaruh signifikan terhadap kinerja karyawan pada PT. Nusamulti Centralestari

Dalam meningkatkan kinerja karyawan pada suatu perusahaan perlu menciptakan tentunya didukung dengan kondisi lingkungan kerja yang memadai, lingkungan kerja merupakan faktorfaktor di luar manusia baik fisik maupun non fisik mencakup hubungan kerja yang terbentuk di suatu instansi antara atasan dan bawahan serta antara sesama karyawan. (Sihombing, 2004).

Hasil penelitian ini menunjukkan bahwa lingkungan kerja berpengaruh signifikan terhadap kinerja karyawan PT. Nusamulti Centralestari, karena tingkat signifikan lebih kecil dari 0.05 yaitu 0.003. Hal ini mendukung penelitian yang dilakukan oleh (Sri Rahayu Muhammad, 2016) yang menyatakan bahwa lingkungan kerja berpengaruh secara signifikan terhadap kinerja karyawan. Dengan demikian hasil penelitian yang dilakukan penulis, memperkuat temuan peneliti sebelumnya.

\section{Pengaruh Stres Kerja Terhadap Kinerja Karyawan}

Dari hasil analisis yang dilakukan bahwa stres kerja memiliki pengaruh yang signifikan terhadap Kinerja Karyawan

Pengaruh stres kerja terhadap kinerja karyawan ditunjukkan oleh nilai koefesien regresi stres kerja sebesar b2 = 
0.224 pada model persamaan regresi linier ganda

$$
\mathrm{Y}=27.137+0.240 \mathrm{X} 1+0.224 \mathrm{X} 2 \text {. }
$$

Maka nilai thitung Stres Kerja (X2) sebesar 2.453 sedangkan nilai ttabel dengan $\mathrm{df}=51$ adalah sebesar 1.675. Maka Ho ditolak dan Ha diterima, dapat dinyatakan bahwa Stres Kerja (X2) memiliki pengaruh signifikan terhadap kinerja karyawan pada PT. Nusamulti Centralestari. Stres yang berkaitan dengan pekerjaandapat menyebabkan ketidakpuasan dalam bekerja. Dalam bekerja muncul ketegangan, kecemasan, mudah marah, kebosanan, konsentrasi berkurang dan menunda-nunda pekerjaan (Robbins, 2012).

Hasil penelitian ini menunjukkan bahwa stres kerja berpengaruh signifikan terhadap kinerja karyawan PT. Nusamulti Centralestari, karena tingkat signifikan lebih kecil dari 0.05 yaitu 0.018. Hal ini mendukung penelitian yang dilakukan oleh (Melda Glenardy, 2013) yang menyatakan bahwa lingkungan kerja dan stres kerja memiliki pengaruh yang positif dan signifikan terhadap kinerja karyawan. Dengan demikian hasil penelitian yang dilakukan penulis, memperkuat temuan peneliti sebelumnya.

Selaras dengan hasil penelitian Zafar, Qadoos, et. al. (2015) yang menunjukkan pengaruh positif dan signifikan stres kerja terhadap kinerja karyawan. Stres kerja yang positif diperlukan dalam karyawan di perbankan, maka dari itu untuk meningkatkan kinerja karyawan pimpinan bank selalu memainkan peran penting pada kinerjakaryawan. Manajer bank mempertahankan tingkat tertentu stres pada karyawan untuk meningkatkan efisiensi dan efektifitas karyawan. Jika stres tidak dikelola dengan benar akan berbahaya bagi karyawan dan juga sebagai organisasi dan mempengaruhi produktivitas pekerja. Oleh karena itu manajemen stres diperlukan dalam organisasi untuk mengatasi stres.

\section{KESIMPULAN \\ Simpulan}

Berdasarkan hasil penelitian dapat disimpulkan hal-hal sebagai berikut:

1. Lingkungan kerja memiliki pengaruh signifikan terhadap kinerja karyawan pada PT. Nusamulti Centralestari.

2. Stres kerja memiliki pengaruh signifikan terhadap kinerja karyawan pada PT. Nusamulti Centralestari.

\section{Saran}

Berdasarkan kesimpulan di atas, saran yang dapat diberikan adalah pihak manajemen PT. Nusamulti Centralestari perlu memperhatikan lingkungan kerja agar selalu kondusif dan nyaman dengan cara memberikan fasilitas kerja. Bagi peneliti selanjutnya yang berminat untuk melanjutkan penelitian ini diharapkan untuk menggunakan variabel lain yang mempengaruhi kinerja karyawan, yaitu mengenai kompensasi kerja karyawan, motivasi kerja karyawan, dan lain-lain. Dan peneliti selanjutnya diharapkan mengambil sampel yang lebih banyak sehingga hasil penelitian lebih valid.

\section{DAFTAR PUSTAKA}

Arikunto, S. 2012. Prosedur penelitian. Jakarta: Rineka Cipta.

Dhermawan, A. A. N. B., Sudibya, I. G. A., Utama, I. W. M. 2012. Pengaruh motivasi, lingkungan kerja, kompetensi dan kompensasi terhadap kepuasan kerja dan kinerja pegawai di lingkungan kantor dinas pekerjaan umum Provinsi Bali. Jurnal Manajemen, Strategi Bisnis dan Kewirausahaan, 6.

Hasibuan, M. S. P. 2013. Manajemen sumber daya manusia, edisi revisi. Jakarta: Bumi Aksara.

Mangkunegara, A. P. 2013. Manajemen sumber daya manusia perusahaan. Bandung: Remaja Rosdakarya.

Moeheriono. 2012. Pengukuran kinerja berbasis kompetensi. Jakarta: PT Raja Grafindo Persada.

Robbins, S. P., Coulter, M. 2012. Management, eleventh edition. 
United States of America: Pearson Education Limited.

Siagian, S. P. 2014. Manajemen sumber daya manusia. Jakarta: Bumi Aksara.

Sihombing, U. 2004. Pengaruh keterlibatan dalam pengambilan keputusan penilaian pada lingkungan kerja dan motivasi berprestasi terhadap kepuasan kerja pamong praja.

Sugiyono. 2012. Metode penelitian kuantitatif kualitatif dan R\&D. Bandung: Alfabeta.
Sutrisno, E. 2016. Manajemen sumber daya manusia. Jakarta: Prenademedia Group.

Zafar, Q., Aayes, A., Tayyab, H., Toqeer, I. Hafiz, I. Y. 2015. The Influence of Job Stress on Employees Performance in Pakistan. American Jurnal of Social Science Research, $1: 221-22$. 